\title{
Apical tissue resection in triangle operation during Whipple's surgery
}

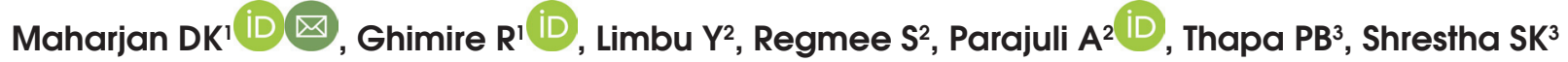

${ }^{1}$ Dhiresh Kumar Maharjan, Assistant Professor; ${ }^{1}$ Roshan Ghimire, Assistant Professor; ${ }^{2}$ Yugal Limbu, Lecturer; ${ }^{2}$ Sujan Regmee, Lecturer; ${ }^{2}$ Anuj Parajuli, Lecturer; ${ }^{3}$ Prabin Bikram Thapa, Professor; ${ }^{3}$ Suman Kumar Shrestha, Professor, Department of Surgery, Kathmandu Medical College, Kathmandu, Nepal.

\begin{abstract}
Background: In pancreatic ductal adenocarcinoma, standardised concepts of radical surgical clearance have not been universally applied.

Objectives: The main objective of this study was to reveal the status of circumferential resection margin of the apical tissue of the triangle namely the confluence of SMA and coeliac trunk in relation to circumferential resection margin of triangle tissue bounded by superior mesenteric artery, common hepatic artery and portal vein when performing the TRIANGLE operation.

Methodology: This was a hospital-based cross-sectional study conducted at Kathmandu Medical College and Teaching Hospital, from $5^{\text {th }}$ September 2020 to $5^{\text {th }}$ December 2020. The study was done after ethical clearance from the Institutional Review Committee of Kathmandu Medical College. All consecutive patients who were subjected for Whipple's operation for pancreatic head and uncinate process were included.

Results: Fifteen patients underwent the "TRIANGLE" operation during a three months period. Median age of the patients was $65 \pm 13.34$ years (range 32-84 years). Medianpreoperative BMI 21.75 \pm 2.5 (range: 18 to 26.7). Regarding histopathological results, an R0 resection was achieved in 9/15 patients. In nine patients,circumferential resection margin(CRM) of both the apical tissue and the rest of the triangle was negative. In the next three patients, the CRM of apical tissue was negative but the triangle tissue was positive whereas in the other three patients CRM of both the apical tissue and the triangle tissue were positive.

Conclusion: This study emphasises the importance of inclusion of apical tissue dissection at the confluence of SMA and coeliac trunk in order to achieve R0 resection without significant short-term morbidity. However, a long-term follow is awaited.
\end{abstract}

Key words: Apical tissue; Pancreatic adenocarcinoma; Triangle operation; Whipple's operation

Access this article online

Website: www.jkmc.com.np

DOI: https://doi.org/10.3126/jkmc.v9i4.38094

\section{HOW TO CITE}

Maharjan DK, Ghimire R, Limbu Y, Regmee S, Parajuli A, Thapa $P B$, et al.. Apical tissue resection in triangle operation during Whipple's surgery. J Kathmandu Med Coll. 2020;9(4):213-8.

Address for correspondence

Dr. Dhiresh Kumar Maharjan MRCSEd, FCPS

Assistant Professor, Department of Surgery

Kathmandu Medical College Teaching Hospital,

Kathmandu, Nepal

E-mail: maharjandhiresh@gmail.com

Copyright @ 2020 Journal of Kathmandu Medical College (JKMC)

ISSN: 2019-1785 (Print), 2091-1793 (Online)

(i) (S) This work is licensed under a Creative Commons Attribution-Non Commercial 4.0 International License.

\section{INTRODUCTION}

Tn pancreatic ductal adenocarcinoma (PDAC), Istandardised concepts of radical surgical clearance have not been universally applied. PDAC are shown to have extensive and early tumour spread to autonomous nerves located alongside the superior mesenteric artery (SMA) and the celiac trunk (CT), compromising clearance of tumour.

In 2017, Hackert et al. described a novel surgical technique called the "TRIANGLE operation" where en bloc removal of the tumour following the adventitial plane of the whole "mesopancreas" from the triangular space limited by the superior mesenteric artery, coeliac trunk, and portal vein².

The aim of this study was to reveal the status of circumferential resection margin of the apical tissue of 
the triangle (CRM apex) namely the confluence of SMA and coeliac trunk in relation to circumferential resection margin of triangle tissue (CRM triangle) bounded by superior mesenteric artery (SMA), common hepatic artery $(\mathrm{CHA})$ and portal vein(PV) when performing the TRIANGLE operation.

\section{METHODOLOGY}

This was a hospital-based cross-sectional study conducted at Kathmandu Medical College and Teaching Hospital in the department of surgery from $5^{\text {th }}$ September 2020 to $5^{\text {th }}$ December 2020. All consecutive patients with resectable pancreatic ductal adenocarcinoma (PDAC) involving head and uncinate process were included after taking informed consent. Ethical clearance from institutional review committee of Kathmandu Medical College was taken (Reference no: 041020202). Borderline resectable or locally advanced pancreatic tumour on cross-sectional imaging (CT or MRI scan) as described according to consensus statement by International Study Group of Pancreatic surgery (ISGPS) 3 or patients found to have peritoneal deposit or hepatic metastasis during diagnostic staging laparoscopy were excluded.

Baseline parameters included age, sex, body mass index (BMI) and American Society of Anaesthesiologist's classification (ASA) ${ }^{4}$ was noted.

Operative parameters included operation time, blood loss, the need for transfusion and details of the surgical procedure. Postoperative pancreatic fistula(POPF) ${ }^{5}$,post pancreatectomy hemorrhage (PPH) ${ }^{6}$ and delayed gastric emptying ${ }^{7}$ was classified according to the International Study Group of Pancreatic surgery (ISGPS) consensus definition and postoperative morbidity were described according to Clavien Dindo Classification ${ }^{8}$.

Surgical technique and the dissection of the triangle: All patients underwent staging laparoscopy to rule out peritoneal or hepatic metastases, followed by laparotomy and the initial steps of the operation included the Whipple's procedure with SMA margin clearance. In this above method, though most of the soft tissue within the triangle is dissected out, apical tissue at the origin of coeliac trunk and SMA are still left behind when described according to the triangle dissection by the Heidelberg technique ${ }^{9}$.

Apex of triangle lies at junction of coeliac axis and origin of SMA-bounded inside by green line. PL ph1pancreatic nerve sheath from head to coeliac axis and PL ph2-pancreatic nerve sheath from uncinate process to
SMA.PL ce -Neurofibrotic tissue around coeliac axis and PLasma -Neurofibrotic tissue around SMA.

In this study, we have labeled the apical tissue of the triangle as a separate entity which consists of periarterial neurolymphatic tissues which are present at the apex of the triangle formed by origin of coeliac trunk and SMA. We marked the edge of apical tissue separately with methylene blue for proper orientation of specimen to look for circumferential resection margin(CRM) and followed the Leeds pathology protocol (LEEPP) where R0 resection has been described as the complete absence of tumour tissue from the resection margins with more than $1 \mathrm{~mm}$, and $\mathrm{R} 1$ resection was defined as the presence of tumour tissue $\leq 1 \mathrm{~mm}$ from a circumferential margin surface, including the pancreatic cut edges, the dissected peripancreatic margin including the dorsal area of the pancreas and SMV groove, and the ventral surface ${ }^{10,11}$.

Patients were categorised into three possibility groups:

Group A: Negative CRM of triangle tissue and negative CRM of apical tissue.

Group B: Positive CRM of triangle tissue but negative CRM of apical tissue.

Group C: Positive CRM of triangle tissue as well as positive CRM of apical tissue.

The data were analyzed using SPSS Statistics for Windows, version 16.0 (SPSS Inc., Chicago, III., USA).

\section{RESULTS}

Fifteen patients with resectable pancreatic heads and uncinate mass underwent the "TRIANGLE" operation during this three months study period.

Medianage of the patients was $65 \pm 13.34$ years (range 32-84 years). Medianpreoperative BMI 21.75 \pm 2.5 (range: 18 to 26.7$)$.

Regarding histopathological results, an $\mathrm{R} 0$ resection was achieved in 9/15 patients. In nine patients, both the CRM apex and the CRM triangle were negative for malignancy. In three patients, CRM apex was negative but the CRM triangle was positive. In three patients, both the CRM apex and the CRM triangle was less than $1 \mathrm{~mm}$ and were labelled as $\mathrm{R} 1$ resection(3/15) mainly in T3 lesions of pancreatic head and uncinate mass.We haven't done frozen section of this apical tissue as it would not benefit further surgically for the radicality of resection for achieving $\mathrm{RO}$ resection. 
Total lymph node (LN) yield ranged between 15 and 45 and NO stage was found in twelve patients and eight patients showed lymphovascular and perineural tumour spread. Lymph node yield of the triangle tissue was separately evaluated and ranged between four to nine lymph nodes.
There were no postoperative mortality, surgical morbidity occurred in 6/15 patients.Complications were classified as Clavien-Dindo grade 2 ( $n=1$ patient), grade $3 a(n=4$ patients) or grade $3 \mathrm{~b}(\mathrm{n}=1$ patient with pseudoaneurysm which was managed with interventional radiological coiling).

Table 1: Demographic profile of patients

\begin{tabular}{|c|c|}
\hline Age(median) & $65 \pm 13.34$ years (range $32-84$ years) \\
\hline Gender (M:F) & $8: 7$ \\
\hline \multicolumn{2}{|l|}{ ASA grading } \\
\hline ASA 2 & 9 \\
\hline ASA 3 & 6 \\
\hline $\mathrm{BMI}($ median) & $21.75 \pm 2.5$ (range: 18 to 26.7 ). \\
\hline Preopearative cross-sectional imaging diameter of tumour size.(mean) & $3.64 \pm 1.69 \mathrm{~cm}$ (range $2-8 \mathrm{~cm})$ \\
\hline \multicolumn{2}{|l|}{ Previous intervention (ERCP or PTBD) } \\
\hline ERCP & 5 \\
\hline PTBD & 2 \\
\hline Operation time(mean) & $322.42 \pm 53.66$ min (range $240-400$ mins), \\
\hline Blood loss(mean) & $439.85 \pm 135.73 \mathrm{ml}($ range $250-800 \mathrm{ml})$ \\
\hline \multicolumn{2}{|l|}{ Pathological staging } \\
\hline T2NO & 7 \\
\hline T2N1 & 3 \\
\hline T2N2 & 2 \\
\hline T3N1 & 2 \\
\hline T3N2 & 1 \\
\hline Morbidity (n-6) & $\begin{array}{l}\text { Postoperative pancreatitis }(n=1) \text {, } \\
\text { POPF grade } B(n=1) \text {, } \\
\text { superficial wound site infections }(n=2) \text {, } \\
\text { chyle leak }(n=1) \\
\text { pseudoaneurysm }(n=1) \\
\text { postoperative diarrhea: }(n=3)\end{array}$ \\
\hline Hospital stay(mean) & $8.92 \pm 2.8$ days (range $5-14$ days). \\
\hline
\end{tabular}

Table 2: Circumferential ResectionMargin (CRM) status between apex and rest of triangle tissue

\begin{tabular}{cccc}
\hline & CRM Apex & CRM triangle & PERCENTAGE \\
\hline Group $A(n-9)$ & Negative & Negative & $60 \%$ \\
Group B $(n-3)$ & Negative & Positive & $20 \%$ \\
Group $C(n-3)$ & Positive & Positive & $20 \%$ \\
\hline
\end{tabular}




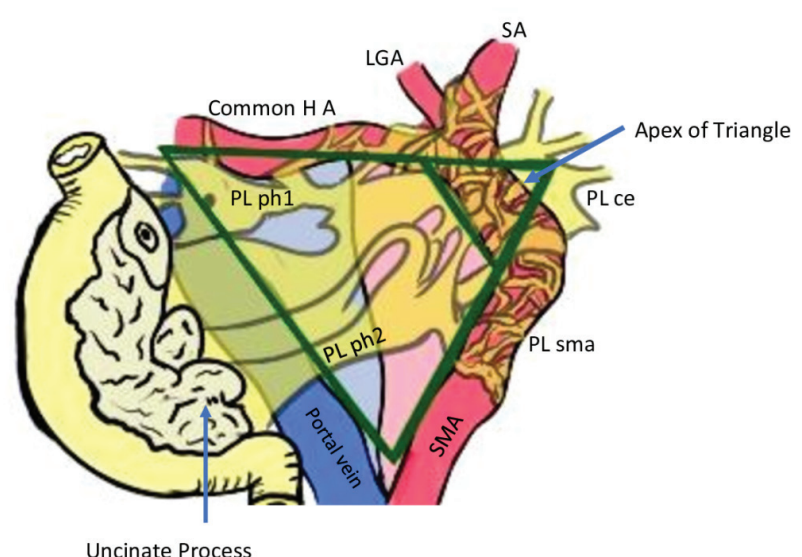

Figure 1: Schematic diagram showing Triangle (Green line) bounded by Portal vein (PV), common hepatic artery (CHA) and Superior Mesenteric Artery (SMA)

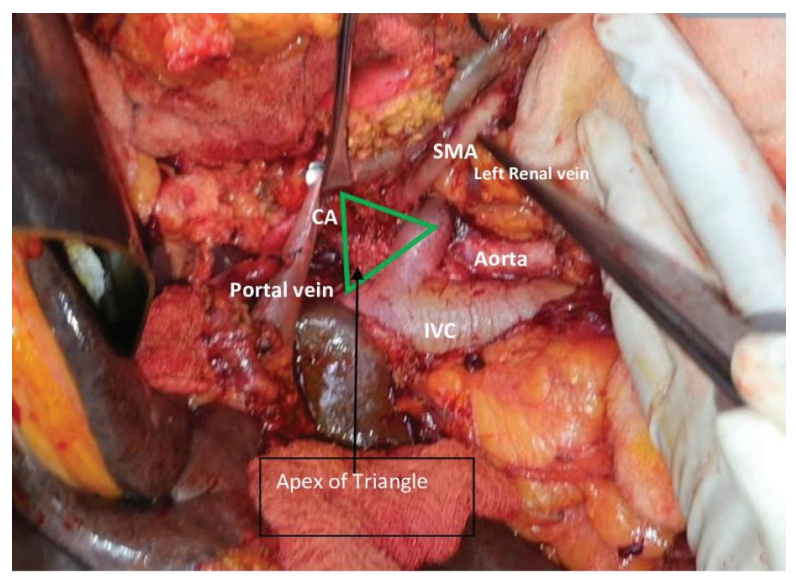

Figure 2: Apex of triangle (Green Triangle) still has Neurofibrotic tissue after SMA margin clearance.CA: Coeliac Axis, SMA: Superior Mesenteric Artery, IVC: Inferior venecava.

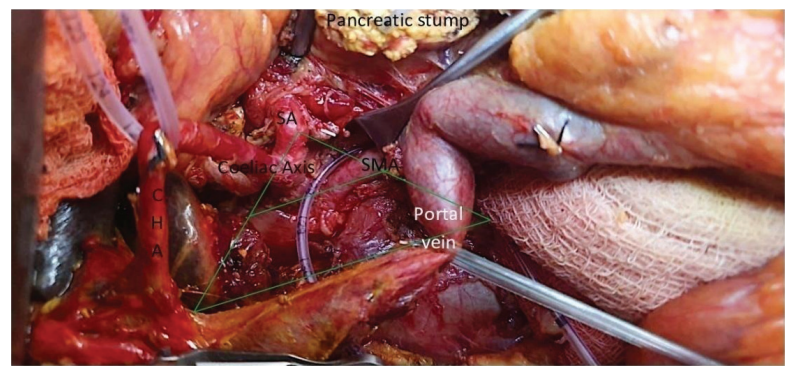

Figure 3: After clearance of apical tissue around Superior Mesenteric artery (SMA) and Coeliac axis(CA).

CHA: Common hepatic artery; SA: Splenic artery; SMA: Superior mesenteric artery.

\section{DISCUSSION}

In our study, nine patients had negative CRM triangular tissue margin and negative CRM apical tissue margin achieving R0 in $60 \%$. However, with clearance of this apical tissue, further three patients (20\%) had negative CRM apical margin that had positive triangular tissue margin. Hence, we think that this achievement of R0 resection of apical margin could be of clinical benefit in terms of preventing local recurrence and improving long term survival. Other three patients had positive triangular tissue along with positive apical tissue giving rise to $\mathrm{R} 1$ resection despite radical surgical treatment where further surgical improvement would not benefit R status.

The only potentially curative treatment for long-term survival of patients with pancreatic cancer is surgical resection with achievement of R0 resection ${ }^{12,13}$. In cases that are operated the medial resection margin along the SMA is the most common site of incomplete tumour clearance $^{14-16}$. Hence, we also think that importance should be given to apical CRM along with triangular lymphovascular tissue and send it separately for histopathological examination before labeling it as $\mathrm{R}$ status.

This study shows the importance of divestment in resectable PADC, which in turn signifies the importance of apical tissue in borderline or locally advanced pancreatic cancer after neoadjuvant treatment. Although previously triangle operation was for borderline PDAC following neoadjuvant treatment, Schneider et al. from the same institute advocated the application of the technique in all patients undergoing the procedure. ${ }^{17}$ With the intent of achieving maximum surgical radicality, Inoue and colleagues, described the "level 3 dissection" in a tissue layer directly on the arterial adventitia in patients undergoing upfront surgery for tumours located at the head and uncinate process of pancreas during pancreatoduodenectomy (PD) with systematic mesopancreas dissection (SMD-PD), using a supracolic anterior artery-first approach have shown the feasibility of this approach with acceptable short term outcomes ${ }^{18}$.

However, we feel that level of divestment might lead to more complication like pseudoaneurysm due to weakening of vessel walls needing radiological intervention as editorial commented by Truty, M. ${ }^{19}$. Inour study, one patient had pseudoaneurysm from inferior pancreaticoduodenal artery which was managed by interventional radiology. Beside it, post-operative diarrhea seems to be noticeable in three patients which 
were managed conservatively with opiods. Study done by Nimura et al. has shown that post-operative diarrhea was significant high in extended lymphadenectomy than in standard lymphadenectomy which was controlled after 6 months of period ${ }^{20}$.

Before term triangle operation have been coined, Igor Ignjatovic et al. ${ }^{21}$ described that extended lymphadenectomy in radical surgical treatment for pancreatic head carcinoma have more numbers of retrieved lymph nodes(24.1 \pm 6.5$)$ then in the standard pancreatoduodenectomy $\quad(18.5 \pm 5) \quad(t=7.110 ; \quad p<0.01)$ which was statistically highly significant. In our study also lymph node yield of the traingle tissue which was separately evaluated have shown to increase lymph node yield ranged between four to nine lymph nodes emphasising the importance of dissection of this triangle tissue and being evaluated separately. However,apical tissue which was sent separately for histopathological examination did not reveal any lymph nodes in it.

\section{REFERENCES}

1. Verbeke CS, Gladhaug IP. Resection margin involvement and tumour origin in pancreatic head cancer. Br J Surg. 2012.99(8):1036-49. [PubMed | FullText | DOI]

2. Hackert T, Strobel O, Michalski CW, et al. The TRIANGLE operation - radical surgery after neoadjuvant treatment for advanced pancreatic cancer: a single arm observational study. HPB. 2017;19:1001-7. [PubMed | FullText | DOI]

3. Bockhorn M, Uzunoglu FG, Adham M, Imrie C, et al. Borderline resectable pancreatic cancer: a consensus statement by the International Study Group of Pancreatic Surgery (ISGPS). Surgery. 2014 Jun;155(6):977-88. [PubMed | FullText | DOI]

4. Saklad M. Grading of patients for surgical procedures. Anesthesiology. 1941 May;2(3):281-284. [FullText | DOI]

5. Bassi C, Marchegiani G, Dervenis C, Sarr M, Abu Hilal $M$, Adham $M$, et al. International study group on pancreatic surgery (ISGPS), the 2016 update of the international study group (ISGPS) definition and grading of postoperative pancreatic fistula: 11 years after. Surgery. 2017;161:584-91.[PubMed | FullText | DOI]

6. Wente MN, Veit JA, Bassi C, et al. Post pancreatectomy hemorrhage (PPH): An International Study Group of Pancreatic Surgery (ISGPS) definition. Surgery. 2007 Jul;142(1):20-5. [PubMed | FullText | DOI]

7. Wente MN, Bassi C, Dervenis C, et al. Delayed gastric emptying (DGE) after pancreatic
Hence this study gives the importance of dissection of apical tissue while performing triangle surgery for pancreatic and peri-pancreatic malignancy.

Limitation of this study is the small number of sample size, however our study shows the importance of apical tissue as a separate entity in triangle operation and should be considered for $\mathrm{R}$ status. We recommend having a large size study with this preliminary study of ours.

\section{CONCLUSION}

This study emphasises the importance of apical tissue divestment around SMA and coeliac trunk in order to achieve RO resection without significant short-term morbidity; however long-term follow needs to be looked after to see for tumour free survival and recurrence.

\section{Declarations of interest: None}

surgery: a suggested definition by the International Study Group of Pancreatic Surgery (ISGPS). Surgery. 2007 Nov;142(5):761-768. [PubMed | FullText | DOI]

8. Dindo D, Demartines N, Clavien P-A. Classification of surgical complications: a new proposal with evaluation in a cohort of 6336 patients and results of a survey. Ann Surg. 2004 Aug;240(2):205-13. [PubMed | FullText | DOI]

9. Schneider M, Strobel O, Hackert T, Büchler MW. Pancreatic resection for cancer-the Heidelberg technique. Langenbecks Arch Surg. 2019 Dec;404(8):1017-22. [PubMed | FullText | DOI]

10. Menon KV, Gomez D, Smith AM, Anthoney A, Verbeke CS. Impact of margin status on survival following pancreatoduodenectomy for cancer: the Leeds Pathology Protocol (LEEPP). HPB (Oxford). 2009 Feb;11(1):18-24. [PubMed | FullText | DOI]

11. Verbeke CS, Menon KV. Redefining resection margin status in pancreatic cancer. HPB (Oxford). 2009;11(4):282-9. [PubMed | FullText | DOI]

12. Yeo CJ, Cameron JL, Lillemoe KD, Sitzmann JV, Hruban $\mathrm{RH}$, Goodman SN et al. Pancreaticoduodenectomy for cancer of the head of the pancreas. 201 patients. Ann Surg 1995; 221: 721-733. [PubMed | FullText | DOI]

13. Ghaneh P, Kleeff J, Halloran CM, Raraty M, Jackson $\mathrm{R}$, Melling $\mathrm{J}$ et al. The impact of positive resection margins on survival and recurrence following resection and adjuvant chemotherapy for pancreatic 
ductal adenocarcinoma. Ann. Surg. 2019; 269:520529. [PubMed | FullText | DOI]

14. Nitecki SS, Sarr MG, Colby TV, van Heerden JA. Long-term survival after resection for ductal adenocarcinoma of the pancreas. Is it really improving? Ann Surg. 1995; 221:59-66. [PubMed | FullText | DOI]

15. Tummers WS, Groen JV, Sibinga Mulder BG, et al. Impact of resection margin status on recurrence and survival in pancreatic cancer surgery. Br J Surg. 2019;106(8):1055-65. [PubMed | FullText | DOI]

16. Van den Broeck A, Sergeant G, Ectors N, Van Steenbergen W, Aerts R, Topal B. Patterns of recurrence after curative resection of pancreatic ductal adenocarcinoma. Eur J Surg Oncol. 2009 Jun;35(6):600-4. [PubMed | FullText | DOI]

17. Schneider M, Strobel O, Hackert T, Büchler MW. Pancreatic resection for cancer-the Heidelberg technique. Langenbecks Arch Surg. 2019 Dec;404(8):1017-22. [PubMed | FullText | DOI]
18. Inoue Y, Saiura A, Oba A, Kawakatsu S, Ono Y, Sato $\mathrm{T}$, et al. Optimal extent of superior mesenteric artery dissection during pancreaticoduodenectomy for pancreatic cancer: Balancing surgical and oncological safety. J Gastrointest Surg. 2019 Jul;23(7):1373-83 [PubMed | FullText | DOI]

19. Truty MJ. Commentary on: Periarterial divestment in pancreatic cancer surgery. Surgery. 2021 May;169(5):1041-3. [PubMed | FullText | DOI]

20. Nimura $Y$, Nagino M, Takao S, Takada T, Miyazaki, Kawarada, $Y$ et al. Standard versus extended lymphadenectomy in radical pancreatoduodenectomy for ductal adenocarcinoma of the head of the pancreas. J Hepatobiliary Pancreat Sci. 2012;19:230-41. [PubMed | FullText | DOI]

21. Ignjatovic I, Knezevic S, Knezevic D, Dugalic V, Micev M, Matic S, et al. Standard versus extended lymphadenectomy in radical surgical treatment for pancreatic head carcinoma. J BUON. 2017 ;22(1):2328. [PubMed | FullText] 